\title{
Bioaccumulation of Cadmium in Siam (Chromolaena odorata) and Node (Synedrella nodiflora) Weeds: Impact of Ethylene Diamine Tetraacetic Acid (EDTA) on Uptake
}

\author{
A. E. Okoronkwo ${ }^{1}$, A. F. Aiyesanmi ${ }^{1}$, A. C. Odiyi ${ }^{2}$, O. M. Sunday ${ }^{1} \&$ I. Shoetan ${ }^{1}$ \\ ${ }^{1}$ Department of Chemistry, School of Sciences, The Federal University of Technology, Akure, Nigeria \\ ${ }^{2}$ Department of Crop, Soil and Pest Management, The Federal University of Technology, Akure, Nigeria \\ Correspondence: A. E. Okoronkwo, Department of Chemistry, School of Sciences, The Federal University of \\ Technology, P.M.B. 704, Akure, Nigeria. E-mail: afamex13@gmail.com
}

\author{
Received: February 10, 2014 Accepted: March 16, 2014 Online Published: April 2, 2014 \\ doi:10.5539/enrr.v4n2p39 URL: http://dx.doi.org/10.5539/enrr.v4n2p39
}

\begin{abstract}
The translocation and accumulation of Cd by Synedrella nodiflora and Chromolaena odorata plants growing in artificially Cd-contaminated soils amended with EDTA or without amendment had been studied to assess the phytoremediation potential of both species. Results showed that roots of $S$. nodiflora had the capacity of taking up a maximum $86.2 \mathrm{mg} / \mathrm{kg}$ of $\mathrm{Cd}$ from the contaminated soil while concentration in shoots amounts to a maximum $73.8 \mathrm{mg} / \mathrm{kg}$. C. odorata was able to accumulate $42.8 \mathrm{mg} / \mathrm{kg}$ and $33.8 \mathrm{mg} / \mathrm{kg}$ in its roots and shoots respectively. The mobility of soil cadmium and the concentration of $\mathrm{Cd}$ in plants were both increased by EDTA amendment. EDTA application facilitated the translocation of $\mathrm{Cd}$ since the concentration in the roots and shoots of $S$. nodiflora increased to $104.9 \mathrm{mg} \mathrm{Cd} / \mathrm{kg}$ and $77.0 \mathrm{mg} \mathrm{Cd} / \mathrm{kg}$ respectively although the amendment effect was more pronounced on $C$. odorata increasing from $42.8 \mathrm{mg} \mathrm{Cd} / \mathrm{kg}$ in roots from non-amended soils to $83.7 \mathrm{mg}$ $\mathrm{Cd} / \mathrm{kg}$ in the roots from amended soils. Despite the improved uptake by $C$. odorata, S. nodiflora appears to be more suitable for phytoremediation of Cd contaminated soils.
\end{abstract}

Keywords: $S$. nodiflora, C. odorata, Cadmium (Cd), Ethylene diamine tetraacetic acid (EDTA)

\section{Introduction}

Heavy metal pollution of soil is a widespread global problem that threatens the safety of ecosystems and human health (Evangelou et al., 2007). Industrial activities has brought attention about a dramatic acceleration of heavy metal contamination in soil (Nriagu, 1979) through practices such as mining and smelting of metalliferous ores, electroplating, gas exhaust, energy and fuel production, fertilizer and pesticide application and generation of municipal waste (Kabata-Pendias \& Pendias, 1989). Amongst the various heavy metals in the environment, Cd, is of great concern because of its toxicity to plants, animals and humans.

In plants, symptoms of $\mathrm{Cd}$ toxicity include for example, lack of root lignification, reduction in chlorophyll $a$ concentration and severe mortality (Reboredo, 2001), reduction of shoot and root weight and chlorophyll's concentration (Chen et al., 2011) with decline in the net photosynthetic rate and stomatal conductance, and finally increase of MDA (malondialdehyde) as the final product of peroxidation of membrane lipids and increase of the non-protein thiols phytochelatins and glutathione in both roots and leaves of rice (Yu et al., 2013). In animals $\mathrm{Cd}$ may be responsible for damage to the lungs and nasal cavity when inhalation occurs, or anemia, liver disease, nerve or brain damage when eating or drinking Cd (ATSDR, 2012).

Heavy metals can enter human diet and accumulate gradually in the human body (Zhu et al., 2003; Rubio et al., 2006) resulting in a number of adverse health effects, such as nephrotoxicity and osteotoxicity (WHO, 1992; Li et al., 2006). Thus, there is an urgent and imperative need to develop efficient techniques for cadmium removal from the environment.

Phytoremediation of heavy metals that are usually persistent in the environment is a low-cost and environmentally friendly alternative to the chemical methods and therefore has attracted much interest over the years (Baker \& Brooks, 1989; Blaylock, 1997). It involves the use of plants to accumulate and remove pollutants from the environment. However, a major constraint of this technique is the poor availability of metals in soil 
solution. In the case of $\mathrm{Cd}$, the $\mathrm{pH}$ is the most important soil factor that influences its availability for possible uptake by plants. Lowering the $\mathrm{pH}$ will favour the availability of the metal.

Complexation of metals by organic complexing agents plays an important role in controlling metal solubility (Reuter \& Purdue, 1977; Naidu \& Harter, 1998). Ethylene diaminetetraacetic acid (EDTA) has been reported as a chelating agent highly efficient at increasing the solubility of heavy metals in soil solutions from the solid phase (Blaylock et al., 1997; Huang et al., 1997; Ebbs et al., 1997; Wu et al., 1999).

The potential of $S$. nodiflora and $C$. odorata for the phytoremediation of Pb-contaminated soil in Nigeria had been reported by Aiyesanmi et al. (2012) showing that $S$. nodiflora has a higher potential for phytoremediation . However, plants are metal specific in their hyper-accumulation ability (Baker \& Brooks, 1989). Hence, this research work aims at investigating the tolerance and accumulation capability of these widely spread weeds in Nigeria to Cd. Also, the effect of EDTA as an enhancement for the phytoremediation potential of these plants had been investigated. The capability of these plants to co-exist without suppressing each other prompted their study under similar experimental parameters.

\section{Materials and Methods}

\subsection{Soil sampling and Characterization}

Soil samples used in these experiments were obtained from a Cd-uncontaminated area within the premises of Federal University of Technology, Akure, Nigeria. Upon collection, the soil was air-dried for three days followed by sieving through a $2 \mathrm{~mm}$ mesh sieve. $0.1 \mathrm{~g}$ of the sieved soil was weighed and digested using concentrated aqua regia. The background $\mathrm{Cd}$ concentration was determined using Atomic Absorption Spectrophotometer (Buck scientific, 210 VGP). The soil $\mathrm{pH}$ was determined in a mixture of soil and deionized water $(1: 2, \mathrm{w} / \mathrm{v}) \mathrm{with}$ a glass electrode (McLean, 1982). Total nitrogen was determined using the Kjeldhal method (Bremner, 1982). Total organic carbon content by Walkey-Black wet oxidation approach (Nelson, 1982). Cation exchange capacity (CEC) was determined using the ammonium acetate method (Rhoades, 1982) while amounts of exchangeable Ca and $\mathrm{Mg}$ were determined by EDTA titration. Total Phosphorus was determined colorimetrically and the soil particle size was measured using the hydrometer method. All reagents used were of analytical grade (BDH Laboratory supplies, Poole, England).

\subsection{Pot Experiments}

Seedlings $C$. odorata and $S$. nodiflora were transplanted into a total of 85 pots containing soil sample which had been treated with $50 \mathrm{mg} / \mathrm{kg}$ NPK fertilizers and allowed to stabilize for about 2 weeks after which they were thinned to one plant per pot. Five out of these pots were used as the control treatment; 40 pots for Cd treatment alone; and 40 pots for Cd + EDTA treatment. The concentrations of 50, 100, 200, 500 and $1000 \mathrm{ppm}$ for both cadmium and EDTA were used. The source of the cadmium was cadmium nitrate. The pots with the plant samples were placed in a screen-house where they are exposed to approximately 12 hours of daylight. Experiments were conducted for a period of 4 weeks.

\subsection{Plant Harvest and Analysis}

Plants on treated and untreated contaminated soil were harvested in duplicates on a weekly basis. Prior to analysis, the plant shoot cutted at the soil surface was harvested, then the soil was broken up and the roots were carefully removed by hand. The shoots and roots were then washed with deionized water, oven dried at $70{ }^{\circ} \mathrm{C}$ for 24 hours, weighed and ground to fine powder. Aliquots of plant powder $(0.5 \mathrm{~g})$ were digested overnight in $5 \mathrm{ml}$

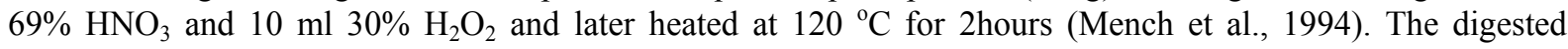
solutions were filtered using Whatman No. 1 filter paper and diluted to $50 \mathrm{ml}$ with deionized water. The concentrations of cadmium in the digested solutions were determined using Atomic Absorption Spectrophotometer (Buck Scientific, 210 VGP). Replicates of data obtained were expressed as means with standard deviation and subjected to one-way ANOVA at $\mathrm{p} \leq 0.05$ using SPSS 17 software.

\section{Results and Discussion}

\subsection{Soil Physicochemical Properties}

The result from the analysis of the soil used in this study is as shown in Table 1. 
Table 1. Soil physicochemical property

\begin{tabular}{|c|c|c|c|c|c|c|c|c|c|c|}
\hline \multirow{2}{*}{$\mathrm{pH}$} & \multicolumn{3}{|c|}{ Texture (\%) } & \multirow{2}{*}{$\begin{array}{l}\text { OM } \\
(\%)\end{array}$} & \multirow{2}{*}{$\begin{array}{c}\text { CEC } \\
(\mathrm{cmol} / \mathrm{kg})\end{array}$} & \multirow{2}{*}{$\begin{array}{c}\mathrm{P} \\
(\%)\end{array}$} & \multirow{2}{*}{$\begin{array}{l}\mathrm{N} \\
(\%)\end{array}$} & \multirow{2}{*}{$\mathrm{Ca} / \mathrm{Mg}$} & \multirow{2}{*}{$\begin{array}{l}\text { EA } \\
(\%)\end{array}$} & \multirow{2}{*}{$\begin{array}{c}\mathrm{Cd} \\
(\mathrm{mg} / \mathrm{kg})\end{array}$} \\
\hline & Sand & Clay & Loam & & & & & & & \\
\hline 6.38 & 62.24 & 21.76 & 14.0 & 5.41 & 14.20 & 0.07 & 9.08 & 5.5 & 2.08 & 1.43 \\
\hline
\end{tabular}

According to Barančíková et al. (2004), $\mathrm{pH}$ and organic matter are two of the most important soil factors that control Cd bioavailability, although Reboredo (1992) has showed that neither the organic matter nor the finest fraction of the soil constituted important binding sites for $\mathrm{Cd}$, thus the bioavailability is not dependent of these factors. Studies conducted by Kuo et al. (2004); Sappin-Didier et al. (2005); Tsadilas et al. (2005) showed that as $\mathrm{pH}$ decreases (acidity increases), the amount of $\mathrm{Cd}$ in their study plants increases due to increased bioavailability of the metal. Furthermore a linear trend between soil $\mathrm{pH}$ and $\mathrm{Cd}$ uptake by plants was reported (Tudoreanu and Phillips, 2004). The $\mathrm{pH}$ value of the study soil will not favour the bioavailability of $\mathrm{Cd}$ in soil solution for possible uptake by plants. The value of organic matter $(5.04 \%)$, nitrogen $(9.08 \%)$ and phosphorus $(0.07 \%)$ recorded indicate that the soil used is fertile for planting. The soil particle size obtained was $62.24 \%$ sand, $21.8 \%$ clay and $14 \%$ silt. The classification on the textural triangle is Sandy-Clay-Loam. The Cation Exchange Capacity (CEC) value of $14.2 \mathrm{cmol} / \mathrm{kg}$ is relatively low due to the high proportion of sand in the soil matrix.

\subsection{Plant Tolerance to Cadmium Contamination and Amendment Treatments}

No visible symptoms of Cd toxicity in $S$. nodiflora plants growing in soils contaminated with $1000 \mathrm{ppm} C \mathrm{Cd}$ were observed during the first week. However, this does not mean that the stress effects were absent. Reboredo (2012) clearly showed that the stress response to $\mathrm{Zn}$, began at the cellular level without immediate translation at the morphophysiological levels, the unusual number of starch grains in the chloroplasts of Halimione portulacoides being the first signs of an abnormal metabolic mechanism. Thus, a similar situation may well occur in our study.

At the end of the second week after initial contamination with 1000 ppm Cd plus EDTA, leaves become yellowish which indicates phytotoxicity This may be due to increased bioavailability of $\mathrm{Cd}$ in soil due to the EDTA amendment. The plants however were able to survive the stress throughout the study period suggesting that they adopted a means of Cd detoxification which may be by exudation (Lasat, 2000).

At the end of the first week, a yellow color appeared on the leaves of C. odorata plants growing in $1000 \mathrm{ppm}$ Cd-contaminated soil amended with EDTA. The growth of the plant, however, was not hindered and the coloration disappeared by the end of the $3 \mathrm{rd}$ week. This observation implies that $\mathrm{Cd}$ contamination at the concentration range considered in this study has no significant effect on C. odorata but higher concentrations could be harmful to the plant.

Plants (C. odorata and S. nodiflora) growing on soils not treated with EDTA did not show any sign of Cd phytotoxicity, regardless the different Cd concentration used. This may be due to the lower bioavailabilty of $\mathrm{Cd}$ in the soil solution compared to that of EDTA amended soil which is expected to be higher (McBride, 1994).

\subsection{Cadmium Uptake Into Plant Parts}

Tables $2 \mathrm{a}$ and $2 \mathrm{~b}$ show the concentration of $\mathrm{Cd}$ in the roots and shoots of plants from Cd-contaminated soils but without EDTA.

As shown in Table 2a, the uptake of $\mathrm{Cd}$ into the roots of plants on untreated contaminated soil increases significantly $(\mathrm{P} \leq 0.05)$ as contaminant concentration increases. For $C$. odorata, the highest uptake of $\mathrm{Cd}$ in the root was $42.8 \pm 0.18 \mathrm{mg} / \mathrm{kg}$ after the fourth week of contamination while $S$. nodiflora gave an uptake of $86.25 \pm$ $1.91 \mathrm{mg} / \mathrm{kg}$ which is $101.5 \%$ higher than that of $C$. odorata. 
Table 2a. Uptake $(\mathrm{mg} / \mathrm{kg})$ of $\mathrm{Cd}$ in the roots of plant on untreated contaminated soil

\begin{tabular}{cccccc}
\hline \multirow{2}{*}{ Plant } & \multicolumn{5}{c}{ Concentration of Cd contaminant } \\
\cline { 2 - 6 } & $50 \mathrm{ppm}$ & $100 \mathrm{ppm}$ & $200 \mathrm{ppm}$ & $500 \mathrm{ppm}$ & $1000 \mathrm{ppm}$ \\
\hline Week 1 & & & & & \\
S. nodiflora & $5.25 \pm 0.32 \mathrm{a}$ & $6.73 \pm 0.43 \mathrm{~b}$ & $9.99 \pm 0.30 \mathrm{c}$ & $18.10 \pm 0.42 \mathrm{~d}$ & $25.25 \pm 0.64 \mathrm{e}$ \\
C. odorata & $2.10 \pm 0.41 \mathrm{a}$ & $7.90 \pm 0.33 \mathrm{~b}$ & $9.0 \pm 0.42 \mathrm{~b}$ & $9.2 \pm 0.57 \mathrm{~b}$ & $26.05 \pm 1.27 \mathrm{c}$ \\
Week 2 & & & & & \\
S. nodiflora & $7.23 \pm 0.28 \mathrm{a}$ & $9.35 \pm 0.71 \mathrm{ab}$ & $15.96 \pm 3.53 \mathrm{ab}$ & $23.4 \pm 1.56 \mathrm{~b}$ & $43.10 \pm 12.16 \mathrm{c}$ \\
C. odorata & $3.80 \pm 1.12 \mathrm{a}$ & $8.82 \pm 0.57 \mathrm{~b}$ & $9.30 \pm 0.3 \mathrm{~b}$ & $9.00 \pm 2.83 \mathrm{~b}$ & $28.80 \pm 0.43 \mathrm{c}$ \\
Week 3 & & & & & \\
S. nodiflora & $10.79 \pm 0.64 \mathrm{a}$ & $21.25 \pm 0.49 \mathrm{~b}$ & $41.29 \pm 0.48 \mathrm{c}$ & $43.60 \pm 0.28 \mathrm{c}$ & $77.63 \pm 1.80 \mathrm{~d}$ \\
C. odorata & $6.80 \pm 3.51 \mathrm{a}$ & $8.90 \pm 0.35 \mathrm{a}$ & $7.90 \pm 0.51 \mathrm{a}$ & $11.21 \pm 0.85 \mathrm{a}$ & $34.40 \pm 2.56 \mathrm{~b}$ \\
Week 4 & & & & & \\
S. nodiflora & $12.11 \pm 1.53$ & $28.20 \pm 2.12 \mathrm{~b}$ & $47.75 \pm 8.2 \mathrm{c}$ & $46.86 \pm 1.27 \mathrm{c}$ & $86.25 \pm 1.91 \mathrm{~d}$ \\
C. odorata & $7.21 \pm 0.01 \mathrm{a}$ & $7.30 \pm 0.52 \mathrm{a}$ & $10.60 \pm 0.61 \mathrm{~b}$ & $18.90 \pm 0.51 \mathrm{c}$ & $42.80 \pm 0.18 \mathrm{~d}$ \\
\hline
\end{tabular}

Values with different lowercase letters (a-e) along the rows are significantly different from each other using LSD test $(\mathrm{P} \leq 0.05)$.

Table $2 \mathrm{~b}$ shows the Cd concentration in the shoots of the plants. C. odorata absorbed $33.8 \pm 0.79 \mathrm{mg} / \mathrm{kg}$ of Cd while S.nodiflora had $73.85 \pm 2.09 \mathrm{mg} / \mathrm{kg} \mathrm{Cd}$ absorbtion which is $118 \%$ higher than that of C. odorata but 26.15 $\%$ lower than the Cd uptake of over $100 \mathrm{mg} / \mathrm{kg}$ that has been recorded by Thlaspi genus, the widely known Cd hyperaccumulator (Kirkham, 2006). In both plants, concentration of Cd were considerably higher in roots than in shoots which conform with previous reports on linseed, sunflower amongst others (Bjelková et al., 2011; Elkhatib et al., 2001). This pattern is also similar to that reported by Aiyesanmi et al. (2012) for the phytoremediation of $\mathrm{Pb}$ - contaminated soil using T. triangulare, S. nodiflora and C. odorata.

Table $2 \mathrm{~b}$. Uptake $(\mathrm{mg} / \mathrm{kg})$ of $\mathrm{Cd}$ in the shoots of plant on untreated contaminated soil

\begin{tabular}{cccccc}
\hline \multirow{2}{*}{ Plant } & \multicolumn{5}{c}{ Concentration of Cd contaminant } \\
\cline { 2 - 6 } & $50 \mathrm{ppm}$ & $100 \mathrm{ppm}$ & $200 \mathrm{ppm}$ & $500 \mathrm{ppm}$ & $1000 \mathrm{ppm}$ \\
\hline Week 1 & & & & & \\
S. nodiflora & $3.76 \pm 0.39 \mathrm{a}$ & $3.88 \pm 0.39 \mathrm{a}$ & $7.56 \pm 0.31 \mathrm{ab}$ & $11.79 \pm 2.70 \mathrm{ab}$ & $15.05 \pm 6.29 \mathrm{~b}$ \\
C. odorata & $1.8 \pm 0.42 \mathrm{a}$ & $5.5 \pm 1.13 \mathrm{~b}$ & $7.1 \pm 0.14 \mathrm{bc}$ & $8.1 \pm 0.57 \mathrm{c}$ & $17.10 \pm 0.85 \mathrm{~d}$ \\
Week 2 & & & & & \\
S. nodiflora & $5.72 \pm 0.88 \mathrm{a}$ & $7.87 \pm 0.79 \mathrm{a}$ & $9.50 \pm 1.56 \mathrm{a}$ & $14.20 \pm 0.42 \mathrm{~b}$ & $32.28 \pm 2.58 \mathrm{c}$ \\
C. odorata & $2.3 \pm 1.36 \mathrm{a}$ & $6.1 \pm 0.37 \mathrm{~b}$ & $8.61 \pm 0.64 \mathrm{c}$ & $8.93 \pm 0.20 \mathrm{c}$ & $21.70 \pm 0.95 \mathrm{~d}$ \\
Week 3 & & & & & \\
S. nodiflora & $10.39 \pm 0.57 \mathrm{a}$ & $10.9 \pm 0.22 \mathrm{a}$ & $25.306 .22 \mathrm{ab}$ & $29.95 \pm 0.21 \mathrm{~b}$ & $57.12 \pm 12.94 \mathrm{c}$ \\
C. odorata & $5.31 \pm 0.17 \mathrm{a}$ & $6.8 \pm 0.37 \mathrm{~b}$ & $10.9 \pm 0.51 \mathrm{bc}$ & $8.5 \pm 0.65 \mathrm{c}$ & $18.8 \pm 0.33 \mathrm{~d}$ \\
Week 4 & & & & & \\
S. nodiflora & $10.36 \pm 0.71 \mathrm{a}$ & $17.2 \pm 0.57 \mathrm{~b}$ & $32.60 \pm 1.41 \mathrm{c}$ & $37.32 \pm 4.10 \mathrm{c}$ & $73.85 \pm 2.09 \mathrm{~d}$ \\
C. odorata & $6.1 \pm 0.37 \mathrm{a}$ & $7.0 \pm 0.57 \mathrm{ab}$ & $12.5 \pm 0.92 \mathrm{~b}$ & $16.6 \pm 0.49 \mathrm{c}$ & $33.8 \pm 0.79 \mathrm{~d}$ \\
\hline
\end{tabular}

Values with different lowercase letters (a-e) along the rows are significantly different from each other using LSD test $(\mathrm{P} \leq 0.05)$. 
In addition, there was a steady increase in the uptake of $\mathrm{Cd}$ by the plants regardless the various concentrations used, as the exposure time increases. Although this study was conducted over a period of 4 weeks, there is a possibility of higher uptake of the metal over more weeks since the plant were able to tolerate the stress initially experienced after contamination.

\subsection{Uptake by Plants on Cd-Contaminated, EDTA-Treated Soil}

According to (Nanda-Kumar et al., 1995), the low solubility of Cd in soil often constitutes a limiting factor for phytoextraction from a contaminated soil. Ethylene diamine tetraacetic acid (EDTA) is probably the chelating agent that is most efficient at increasing the solubility of heavy metals in soil solutions by desorbing the metals from the solid phase and form stable complexes with them (Blaylock, 1997; Huang, 1997; Ebbs, 1997; Wu et al., 1999). Table $3 \mathrm{a}$ and $3 \mathrm{~b}$ show the concentration of $\mathrm{Cd}$ in the roots and shoots of plants grown on soils treated with EDTA. There was a significant increase in the uptake of $\mathrm{Cd}$ into the plant parts. The highest absorbtion of $\mathrm{Cd}$ was recorded on the $1000 \mathrm{ppm}$ contaminanted soil at the fourth week.

Table 3a. Uptake $(\mathrm{mg} / \mathrm{kg})$ of Cd in the roots of plant on EDTA treated contaminated soil

\begin{tabular}{cccccc}
\hline \multirow{2}{*}{ Plant } & \multicolumn{5}{c}{ Concentration of Cd contaminant } \\
\cline { 2 - 6 } & $50 \mathrm{ppm}$ & $100 \mathrm{ppm}$ & $200 \mathrm{ppm}$ & $500 \mathrm{ppm}$ & $1000 \mathrm{ppm}$ \\
\hline Week 1 & & & & & \\
S. nodiflora & $8.18 \pm 0.11 \mathrm{a}$ & $10.01 \pm 0.43 \mathrm{a}$ & $14.68 \pm 0.51 \mathrm{a}$ & $30.53 \pm 5.48 \mathrm{~b}$ & $42.98 \pm 0.74 \mathrm{c}$ \\
C. odorata & $4.21 \pm 0.63 \mathrm{a}$ & $9.8 \pm 1.25 \mathrm{ab}$ & $12.49 \pm 3.52 \mathrm{ab}$ & $18.32 \pm 6.11 \mathrm{~b}$ & $38.12 \pm 5.09 \mathrm{c}$ \\
Week 2 & & & & & \\
S. nodiflora & $9.95 \pm 0.15 \mathrm{a}$ & $21.6 \pm 8.49 \mathrm{a}$ & $34.12 \pm 0.99 \mathrm{~b}$ & $47.01 \pm 4.74 \mathrm{c}$ & $56.92 \pm 3.38 \mathrm{c}$ \\
C. odorata & $5.80 \pm 0.65 \mathrm{a}$ & $12.10 \pm 3.96 \mathrm{ab}$ & $16.83 \pm 5.09 \mathrm{ab}$ & $22.06 \pm 5.01 \mathrm{~b}$ & $49.11 \pm 6.11 \mathrm{c}$ \\
Week 3 & & & & & \\
S. nodiflora & $12.15 \pm 1.27 \mathrm{a}$ & $24.65 \pm 1.63 \mathrm{a}$ & $48.35 \pm 0.78 \mathrm{~b}$ & $51.95 \pm 2.33 \mathrm{~b}$ & $89.72 \pm 2.99 \mathrm{c}$ \\
C. odorata & $6.90 \pm 5.09 \mathrm{a}$ & $15.21 \pm 1.30 \mathrm{ab}$ & $20.11 \pm 5.04 \mathrm{ab}$ & $28.26 \pm 5.09 \mathrm{~b}$ & $61.16 \pm 8.78 \mathrm{c}$ \\
Week 4 & & & & & \\
S. nodiflora & $15.08 \pm 1.91 \mathrm{a}$ & $32.04 \pm 3.11 \mathrm{~b}$ & $53.6 \pm 5.37 \mathrm{c}$ & $57.3 \pm 0.57 \mathrm{c}$ & $104.9 \pm 7.07 \mathrm{~d}$ \\
C. odorata & $7.9 \pm 1.25 \mathrm{a}$ & $23.1 \pm 3.96 \mathrm{~b}$ & $28.6 \pm 0.65 \mathrm{bc}$ & $36.70 \pm 8.78 \mathrm{c}$ & $83.70 \pm 5.09 \mathrm{~d}$ \\
\hline
\end{tabular}

Values with different lowercase letters (a-e) along the rows are significantly different from each other using LSD test $(\mathrm{P} \leq 0.05)$.

In fact $104.9 \mathrm{ppm} \mathrm{Cd}$ was measured in the root of $S$. nodiflora an increase of $21.6 \%$ over the concentration recorded for the roots collected from untreated (without EDTA) contaminated soils. Conversely, the concentrations of $\mathrm{Cd}$ in the $S$. nodiflora shoots collected from Cd-contaminated soils and Cd-contaminated soils plus EDTA were very similar suggesting that the translocating of $\mathrm{Cd}$ from roots to shoots in S. nodiflora is poor which may be due to efficient immobilization mechanisms in the below-ground organs, which agrees with Aiyesanmi et al. (2012) who verified that $S$. nodiflora exhibited a lower translocation of $\mathrm{Pb}$ when compared to $C$. odorata. Similarly for C. odorata, the highest uptake in the root was recorded for the plant on $1000 \mathrm{ppm}$ contaminated soil treated with EDTA. The uptake of $\mathrm{Cd}$ into its root increased from $42.8 \pm 0.18 \mathrm{mg} / \mathrm{kg}$ (untreated soil) to $83.7 \pm 5.09 \mathrm{mg} / \mathrm{kg}$ representing an increase of $95.6 \%$ while in the shoot an increase of $103.9 \%$ was recorded. The increase in uptake was due to the ability of EDTA to increase the bioavailability of Cd in soil solution. In addition, the EDTA significantly increased the uptake of $\mathrm{Cd}$ more in $C$. odorata than in $S$. nodiflora. This is evident in the yellowing of leaves of $S$. nodiflora on $1000 \mathrm{ppm}$ contaminated soil treated with EDTA after two weeks of contamination while $C$. odorata on the same treatment recovered from the initial stress observed and survived throughout the study period. 
Table 3b. Uptake $(\mathrm{mg} / \mathrm{kg})$ of $\mathrm{Cd}$ in the shoots of plant on EDTA treated contaminated soil

\begin{tabular}{cccccc}
\hline \multirow{2}{*}{ Plant } & \multicolumn{5}{c}{ Concentration of Cd contaminant } \\
\cline { 2 - 6 } & $50 \mathrm{ppm}$ & $100 \mathrm{ppm}$ & $200 \mathrm{ppm}$ & $500 \mathrm{ppm}$ & $1000 \mathrm{ppm}$ \\
\hline Week 1 & & & & & \\
S. nodiflora & $5.5 \pm 0.23 \mathrm{a}$ & $6.85 \pm 0.78 \mathrm{ab}$ & $8.49 \pm 0.79 \mathrm{~b}$ & $19.37 \pm 0.60 \mathrm{c}$ & $24.90 \pm 1.27 \mathrm{~d}$ \\
C. odorata & $3.88 \pm 1.30 \mathrm{a}$ & $9.41 \pm 0.79 \mathrm{a}$ & $11.60 \pm 5.09 \mathrm{a}$ & $16.10 \pm 6.11 \mathrm{a}$ & $35.21 \pm 13.98 \mathrm{~b}$ \\
Week 2 & & & & & \\
S. nodiflora & $7.28 \pm 1.80 \mathrm{a}$ & $11.57 \pm 2.51 \mathrm{a}$ & $13.12 \pm 1.41 \mathrm{a}$ & $22.72 \pm 3.72 \mathrm{~b}$ & $28.5 \pm 6.36 \mathrm{~b}$ \\
C. odorata & $4.60 \pm 0.79 \mathrm{a}$ & $10.11 \pm 6.11 \mathrm{a}$ & $14.01 \pm 2.83 \mathrm{a}$ & $18.90 \pm 6.11 \mathrm{a}$ & $42.25 \pm 8.78 \mathrm{~b}$ \\
Week 3 & & & & & \\
S. nodiflora & $9.83 \pm 2.02 \mathrm{a}$ & $11.80 \pm 0.11 \mathrm{ab}$ & $17.25 \pm 0.41 \mathrm{~b}$ & $29.12 \pm 1.56 \mathrm{c}$ & $58.03 \pm 4.10 \mathrm{~d}$ \\
C. odorata & $5.6 \pm 3.96 \mathrm{a}$ & $13.35 \pm 5.09 \mathrm{ab}$ & $18.70 \pm 5.02 \mathrm{ab}$ & $23.98 \pm 0.79 \mathrm{~b}$ & $58.71 \pm 6.11 \mathrm{c}$ \\
Week 4 & & & & & \\
S. nodiflora & $11.35 \pm 1.27 \mathrm{a}$ & $24.16 \pm 8.86 \mathrm{~b}$ & $34.25 \pm 0.91 \mathrm{bc}$ & $38.47 \pm 0.98 \mathrm{c}$ & $77.02 \pm 0.99 \mathrm{~d}$ \\
C. odorata & $6.11 \pm 0.82 \mathrm{a}$ & $18.72 \pm 5.08 \mathrm{ab}$ & $25.28 \pm 8.78 \mathrm{~b}$ & $29.86 \pm 0.45 \mathrm{~b}$ & $68.93 \pm 6.14 \mathrm{c}$ \\
\hline
\end{tabular}

Values with different lowercase letters (a-e) along the rows are significantly different from each other using LSD test $(\mathrm{P} \leq 0.05)$.

\subsection{Phytoremediation Potential}

The success of phytoremediation greatly depends on the ability of a plant to absorb a certain contaminant into its root and subsequent translocation to the above ground parts where they can be easily harvested (Nanda-Kumar et al., 1995). The potentials of these plants for phytoremediation had been investigated using the bioaccumulation factor (BF) and translocation factor (TF). The bioaccumulation factor is the ratio of the metal concentration in the shoot to that in the soil while the translocation factor is the ratio of metal in the shoot to that in the root.

\subsubsection{Bioaccumulation Factor}

Of the two study plants, S. nodiflora gave a higher BF ranging from 0.52-0.84 across the various contaminant concentration for soil not treated with EDTA as shown in figure 1a while $C$. odorata had a BF ranging from $0.23-0.44$. This further establishes the higher potential of S. nodiflora as a phytoremediator of Cd-contaminated soil over $C$. odorata. For EDTA-treated soil (Figure 1b), the BF of $S$. nodiflora was 0.57-0.91 while that of $C$. odorata ranges from $0.45-0.86$. This corresponds to an increase of $8.8 \%$ in the BF of $S$. nodiflora while that observed in C. odorata is $92.6 \%$. This shows that EDTA treatment favours the increased uptake of Cd by $C$. odorata more than $S$. nodiflora which may be due to the higher tolerance of $C$. odorata to the EDTA-metal complex that is formed. 


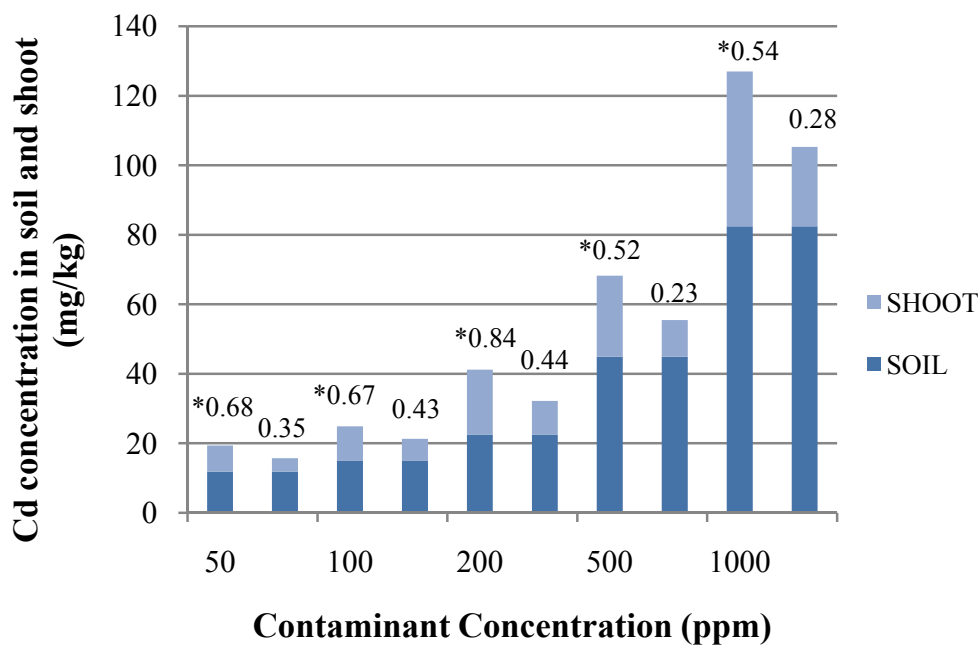

Figure 1a. Bioaccumulation factor (BF) of S. nodiflora and C. odorata on untreated soil

* The first bar under each contaminant concentration represent the BF of $S$. nodiflora while the second bar represents the BF of $C$. odorata.

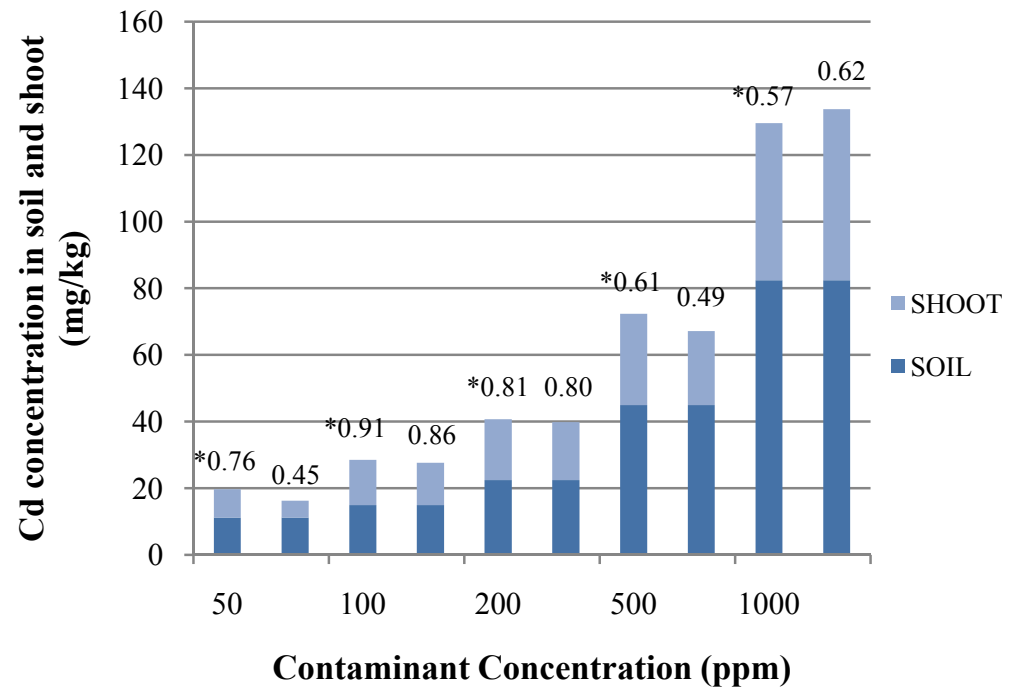

Figure 1b. Bioaccumulation factor (BF) of S. nodiflora and C. odorata on EDTA-treated soil

* The first bar under each contaminant concentration represent the BF of $S$. nodiflora while the second bar represents the BF of $C$. odorata.

\subsubsection{Translocation Factor}

S. nodiflora, although gave a higher accumulation of $\mathrm{Cd}$, demonstrated a lower ability to translocate the metal from the root to shoot. Figure 2a shows the TF of plants on contaminated soil not treated with EDTA. $S$. nodiflora gave a TF ranging from 0.61-0.85 while $C$. odorata recorded a higher TF from 0.69-0.94. A hyper-accumulator plant should demonstrate a TF or shoot: root ratio 1 (Baker \& Brooks, 1989). The plants in this study, particularly $C$. odorata, have performed fairly close to this standard. The lower TF of $S$. nodiflora compared to C. odorata for the phytoremediation of $\mathrm{Pb}$ had also been reported (Aiyesanmi et al., 2012).

Furthermore, treatment with EDTA did not change the order of the TF as $C$. odorata gave a higher value of 0.81-0.89 while $S$. nodiflora had 0.49-0.75 (Figure $2 \mathrm{~b}$ ) which is quite a reduction over that recorded for it on the untreated soil. It thus appears that despite the increased bioavailability of the metal by amending the soil with EDTA, it had a retrogressive effect on the potential of S. nodiflora as a phytoremediator of Cd which may be as a result of the toxicity of the EDTA-metal complex to the plant. 


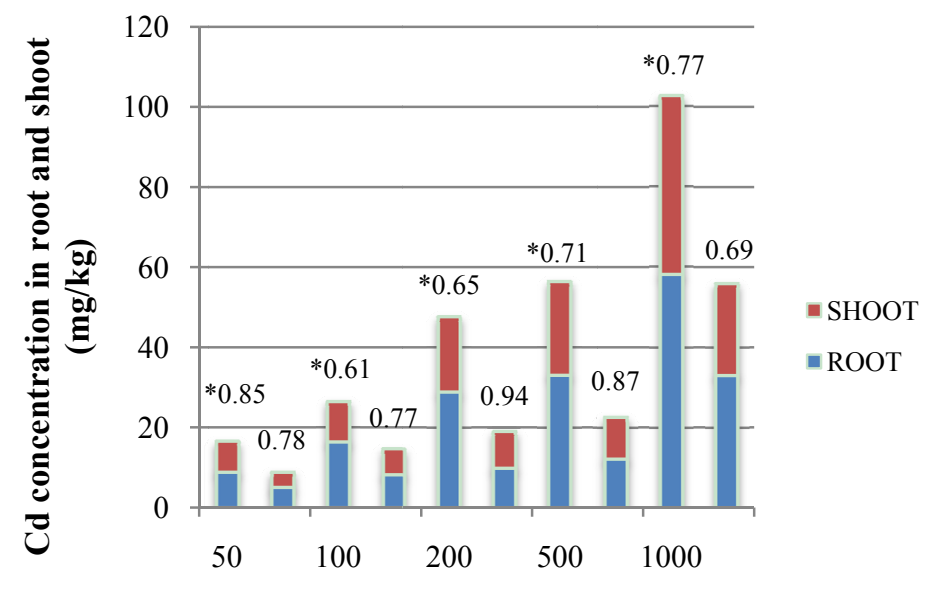

Contaminant Concentration (ppm)

Figure 2a. Transfer factor (TF) of $S$. nodifora and $C$. odorata on untreated soil

* The first bar under each contaminant concentration represent the TF of $S$. nodiflora while the second bar represents the TF of $C$. odorata.

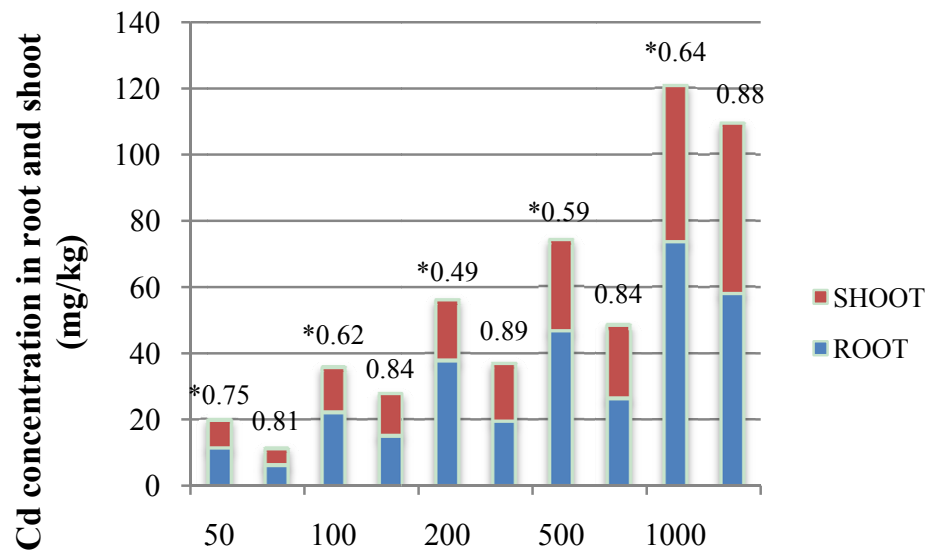

Contaminant Concentration (ppm)

Figure 2b. Transfer factor (TF) of S. nodiflora and C. odorata on EDTA-treated soil

* The first bar under each contaminant concentration represent the TF of S. nodiflora while the second bar represents the TF of $C$. odorata.

\section{Conclusion}

The plants investigated in this study showed a high potential to bioaccumulate $\mathrm{Cd}$ without compromising apparently, a balanced development. In Cd-contaminated soils without EDTA amendment $S$. nodiflora exhibited the highest absorption rates with $86.25 \mathrm{mg} \mathrm{Cd} / \mathrm{kg}$ in the roots and $73.85 \mathrm{mg} \mathrm{Cd} /-\mathrm{kg}$ in the shoots while $C$. odorata recorded a lower uptake of $42.8 \mathrm{mg} \mathrm{Cd} / \mathrm{kg}$ and $33.8 \mathrm{mg} \mathrm{Cd} / \mathrm{kg}$ in its roots and shoots respectively. Amendment with EDTA gave us an enhanced uptake of $104.9 \mathrm{mg} \mathrm{Cd} / \mathrm{kg}$ in the roots and $77.0 \mathrm{mg} \mathrm{Cd} / \mathrm{kg}$ in the shoot of $S$. nodiflora corresponding to an increase of $21.6 \%$ and $4.29 \%$ in the roots and shoots respectively. EDTA amendment, appears to favour $C$. odorata more since an increase in $\mathrm{Cd}$ concentration of approximately $100 \%$ in plant organs. However, it seems to us that $S$. nodiflora is the best suitable and a promising plant in the phytoremediation of $\mathrm{Cd}$-contaminated soil since it was able to achieve a high uptake of $\mathrm{Cd}$ into its tissues without EDTA amendment. 


\section{Acknowledgements}

The authors will like to acknowledge the management of the Federal University of Technology, Akure for the research grant given towards this project.

\section{References}

Aiyesanmi, A. F, Okoronkwo, A. E., \& Sunday, O. M. (2012). Lead accumulation in Siam weed (Chromolaena odorata), Node weed (Synedrella nodiflora) and Water leaf (Talinum triangulare): Potential phytoremediators. Arch. Appl. Sci. Res., 4, 360-371.

ATSDR. (2012). Agency for Toxic substances and Disease Registry. Public Health Statement for Cadmium. Retrieved September, 2012, from http://www.atsdr.cdc.gov/phs/phs.asp?id=46\&tid=15

Baker, A. J. M., \& Brooks, R. R. (1989). Terrestrial higher plants which hyperaccumulate metallic elements - A review of their distribution, ecology and phytochemistry. Biorecovery, 1, 81-126.

Barančíková, G., Madaras, M., \& Rybár, O. (2004). Crop contamination by selected trace elements. J. Soils Sed., 4, 37-42. http://dx.doi.org/10.1007/BF02990827

Bjelkova, M., Gencurova, V., \& Griga, M. (2011). Accumulation of cadmium by flax and linseed cultivars in field-simulated conditions: A potential for phytoremediation of Cd-contaminated soils. Industrial Crops and Products, 33, 761-774. http://dx.doi.org/10.1016/j.indcrop.2011.01.020

Blaylock, M. J., Salt, D. E., Dushenkov, S., Zakharova, O., Gussman, C., Kapulnik, Y., ... Raskin, I. (1997). Enhanced accumulation of $\mathrm{Pb}$ in Indian mustard by soil- chelating agents, Environ. Sci. Technol., 31, 860-865. http://dx.doi.org/10.1021/es960552a

Bremner, J. M., \& Mulvaney, C. S. (1982). Nitrogen total content. In A. L. Page, R. H. Miller, \& D. R. Keeney (Eds.), Methods of Soil Analysis. Part 2. Chemical and Microbiological Properties (Agronomy 9, 2nd ed.), Agronomy Society of America and Soil.

Chen, X., Wang, J., Shi, Y., Zhao, M. Q., \& Chi, G. Y. (2011). Effects of cadmium on growth and photosynthetic activities in pakchoi and mustard. Bot. Studies ,52, 41-46.

Ebbs, S. D., Lasat, M. M., Brady, D. J., Cornish, J., Gordon, R., \& Kochian, L. V. (1997). Phytoextraction of cadmium and zinc from a contaminated site. J. Environ. Qual., 26, 1424-1430. http://dx.doi.org/10.2134/jeq1997.00472425002600050032x

Elkhatib, E. A., Thabet, A. G., \& Mahdy, A. M. (2001). Phytoremediation of cadmium contaminated soils: role of organic complexing agents in cadmium phytoextraction. Land Contamination \& Reclamation, 9(4), 359-366.

Evangelou, M. W. H., Bauer, U., Ebel, M., \& Schaeffer, A. (2007). The influence of EDDS and EDTA on the uptake of heavy metals of $\mathrm{Cd}$ and $\mathrm{Cu}$ from soil with tobacco Nicotiana tabacum. Chemosphere, 68,345-353. http://dx.doi.org/10.1016/j.chemosphere.2006.12.058

Huang, J. W., Chen, J., Berti, W. R., \& Cunningham, S. D. (1997). Phytoremediation of lead-contaminated soils: Role of synthetic chelates in lead phytoextraction. Environ. Sci. Technol., 31, 800-805. http://dx.doi.org/10.1021/es9604828

Kabata-Pendias, A., \& Pendias, H. (1989). Trace elements in the soil and plants. Boca Raton, FL.: CRC Press.

Kirkham, M. B. (2006). Cadmium in plants on polluted soils: Effects of soil factors, hyperaccumulation, and amendments. Geoderma, 137, 19-32. http://dx.doi.org/10.1016/j.geoderma.2006.08.024

Kuo, S., Huang, B., \& Bembenek, R. (2004). The availability to lettuce of zinc and cadmium in a zinc fertilizer. Soil Science, 169, 363-373. http://dx.doi.org/10.1097/01.ss.0000128014.15268.d9

Lasat, M. M., (2000). Phytoremediation of metals from contaminated soil: A review of plant $/ \mathrm{soil} / \mathrm{metal}$ and assessment of pertinent agronomic issues. J. of Harz. Subs. Research, 2, 1-25.

Li, J. T., Qiu, J. W., Wang, X. W., Zhong, Y., Lan, C. Y., \& Shu, W. S. (2006). Cadmium contamination in orchard soils and fruit trees and its potential health risk in Guangzhou, China. Environ. Pollut., 143, 159-165.

McBride, M. B. (1994). Environmental Chemistry of Soils (pp. 336-337). New York, NY: Oxford University Press.

McLean, E. O. (1982). Soil pH and lime requirement. In A. L. Page, R. H. Miller, \& D. R. Keeney (Eds.), 
Methods of Soil Analysis. Part 2.Chemical and Microbiological Properties (Agronomy Monograph 9, 2nd ed., pp. 199-224). Madison, WI, USA: Agronomy Society of America and Soil Science Society of America.

Mench, M. J., Didier, V. L., Loffler, M., Gomez, A., \& Masson, P. (1994). A mimicked in situ remediation study of metal-contaminated soils with emphasis on cadmium and lead. J. Environ. Qual., 23, 58-63. http://dx.doi.org/10.2134/jeq1994.23158x

Naidu, R., \& Harter, R. D. (1998). Effect of different organic ligands on cadmium sorption by and extractability from soils. Soil Sci. Soc. Am. J., 62, 644-650. http://dx.doi.org/10.2136/sssaj1998.03615995006200030014x

Nanda-Kumar, P. B. A., Dushenkov, V., Motto, H., \& Raskin, I. (1995). Phytoextraction: The use of plants to remove heavy metals from soils. Environ. Sci. Technol., 29, 1232-1238. http://dx.doi.org/10.1021/es00005a014

Nelson, D. W., \& Sommers, L. E. (1982). Total carbon, organic carbon, and organic matter. In A. L. Page, R. H. Miller, \& D. R. Keeney (Eds.), Methods of Soil Analysis. Part 2. Chemical and Microbiological Properties (Agronomy Monograph 9, 2nd ed., pp. 539-577). Madison, WI, USA: Agronomy Society of America and Soil Science Society of America.

Nriagu, J. O. (1979). Global inventory of natural and anthropogenic emissions of trace metals to the atmosphere. Nature, 279, 409-411. http://dx.doi.org/10.1038/279409a0

Reboredo, F. (1992). Cadmium accumulation by Halimione portulacoides (L.) Aellen. A seasonal study. Mar. Environ. Res., 33, 17-29. http://dx.doi.org/10.1016/0141-1136(92)90003-5

Reboredo, F. (2001). Cadmium Uptake by Halimione portulacoides: An Ecophysiological Study Bull. Environ. Contam. Toxicol., 67, 926-933. http://dx.doi.org/10.1007/s001280210

Reboredo, F., (2012). Zinc compartmentation in Halimione portulacoides (L.) Aellen and some effects on leaf ultrastructure. Environ. Sci. Pollut. Res., 19, 2644-2657. http://dx.doi.org/10.1007/s11356-012-0757-8

Reuter, J. H., \& Purdue, E. M. (1977). Importance of heavy metal - organic matter interactions in natural waters. Geo-chim. Cosmochim. Acta, 41, 325-334. http://dx.doi.org/10.1016/0016-7037(77)90240-X

Rhoades, J. D. (1982). Cation exchange capacity. In A. L. Page, R. H. Miller, \& D. R. Keeney (Eds.), Methods of Soil Analysis. Part 2. Chemical and Microbiological Properties (Agronomy Monograph 9, 2nd ed., pp. 149-157). Madison, WI, USA: Agronomy Society of America and Soil Science Society of America.

Rubio, S. C., Hardisson, A., Reguera, J. I., Revert, C., Lafuente, M. A., \& Gonzalez-Iglesias, T. (2006). Cadmium dietary intake in the Canary Islands. Environ. Res., 100, 123-129. http://dx.doi.org/10.1016/j.envres.2005.01.008

Sappin-Didier, V., Vansuyts, G., Mench, M., \& Briat, J. F. (2005). Cadmium availability at different soil pH to transgenic tobacco overexpresing ferritin. Plant and Soil, 270, 189-197. http://dx.doi.org/10.1007/s11104-004-1494-7

Tsadilas, C. D., Karaivazoglou, N. A., Tsotsolis, N. C., Stamatiadis, S., \& Samaras, V. (2005). Cadmium uptake by tobacco as affected by liming, $\mathrm{N}$ form, and year of cultivation. Environ. Pollut., 134, 239-246. http://dx.doi.org/10.1016/j.envpol.2004.08.008

Tudoreanu, L., \& Phillips, C. J. C. (2004). Modeling cadmium uptake and accumulation in plants. Adv. Agron., 84, 121-157. http://dx.doi.org/10.1016/S0065-2113(04)84003-3

WHO. (1992). Cadmium. In Environmental Health Criteria, WHO, Geneva, p. 134.

Wu, J., Hsu, F. C., \& Cunningham, S. D. (1999). Chelate-assisted Pb phytoextraction: Pb availability, uptake and translocation constraints. Environ. Sci. Technol., 33, 1898-1904. http://dx.doi.org/10.1021/es9809253

Yu, F., Liu, K., Li, M., Zhou, Z., Deng, H., \& Chen, B. (2013). Effects of cadmium on enzymatic and non-enzymatic antioxidative defences of rice (Oryza sativa L.). Int. J. Phytoremediat., 15, 513-521. http://dx.doi.org/10.1080/15226514.2012.702807

Zhu, Y. G., Zhao, Z. Q., Li, H. Y., Smith, S. E., \& Smith, F. A. (2003). Effect of zinc-cadmium interactions on the uptake of zinc and cadmium by winter wheat (Triticum aestivum) grown in pot culture. Bull. Environ. Contam. Toxicol., 71, 1289-1296. http://dx.doi.org/10.1007/s00128-003-0230-y 


\section{Copyrights}

Copyright for this article is retained by the author(s), with first publication rights granted to the journal.

This is an open-access article distributed under the terms and conditions of the Creative Commons Attribution license (http://creativecommons.org/licenses/by/3.0/). 